\title{
NONLINEAR MODELS BASED ON QUANTILES IN THE FITTING OF GROWTH CURVES OF PEPPER GENOTYPES
}

\author{
Ana Carolina Ribeiro de OLIVEIRA ${ }^{1}$ \\ Paulo Roberto CECON ${ }^{1}$ \\ Guilherme Alves PUIATTI ${ }^{1}$ \\ Maria Eduarda da Silva GUIMARÃES ${ }^{2}$ \\ Cosme Damião CRUZ ${ }^{2}$ \\ Fernando Luiz FINGER ${ }^{3}$ \\ Moysés NASCIMENTO ${ }^{1}$ \\ Mário PUIATTI $^{3}$ \\ Maurício Silva LACERDA ${ }^{1}$
}

- ABSTRACT: This study aimed to fit nonlinear regression models to model the growth of the characters fruit length (FL) and fruit width (FW) of pepper genotypes (Capsicum annuum L.) over time using the method of ordinary least squares (OLS); and identify the model with the best fit and compare it to the model obtained via nonlinear quantile regression $(\mathrm{QR})$ in the $0.25,0.5$, and 0.75 quantiles. Three regression models (Logistic, Gompertz, and von Bertalanffy) and four fit quality evaluators were adopted: Akaike information criterion, residual mean absolute deviation, and parametric and intrinsic curvature measurements. Five commercial genotypes of pepper were evaluated. Characters FL and FW were evaluated weekly from seven days after flowering, totaling ten measurements. In the estimation by OLS, the Logistic and von Bertalanffy models were considered adequate according to the quality evaluators. In the comparison between the models above by OLS and QR, the superiority of models obtained by QR was verified for the character FL. For the character FW, QR was efficient in three out of the five genotypes, being a valuable alternative in the study of fruit growth.

- KEYWORDS: Capsicum annuum; ordinary least squares; quantile regression.

\section{Introduction}

Pepper (Capsicum spp.) is one of the main horticultural crops in the world, with wide variation of extrinsic and intrinsic characteristics and consequently wide plasticity of uses,

\footnotetext{
${ }^{1}$ Universidade Federal de Viçosa - UFV, Departamento de Estatística, CEP: 36570-900, Viçosa, MG, Brasil. E-mail: ana.oliveira8@outlook.com.br; cecon@ufv.br; guilherme@dpi.ufv.br; mnascimento@ufv.br; mauricio.lacerda@ufv.br

${ }^{2}$ Universidade Federal de Viçosa - UFV, Departamento de Biologia Geral, CEP: 36570-900, Viçosa, MG, Brasil. E-mail: mariaeduarda.ufv@gmail.com; cruz@ufv.br

${ }^{3}$ Universidade Federal de Viçosa - UFV, Departamento de Fitotecnia, CEP: 36570-900, Viçosa, MG, Brasil. E-mail:finger@ufv.br; mpuiatti@ufv.br
} 
such as in cooking, in industry, and as ornamental plant (JARRET et al., 2019, TRIPODI et al., 2019). Among cultivated species, Capsicum annuum L. is the best known, with the greatest economic representation and worldwide distribution (PICKERSGILL, 1997, HWANG et al., 2013, TRIPODI et al., 2019).

The increasing commercial interest in pepper fruits has contributed to the appearance of a large number of cultivars that combine high yield, resistance to diseases, aesthetic attractiveness, and other traits (SASU et al., 2013; NEITZKE et al., 2016; CABRAL et al., 2017).

Thus, global pepper production has been showing continuous growth in harvested area and yield (JARRET et al., 2019). Asia contributed with $68.4 \%$ of the world production of Capsicum spp. (fresh fruit), while the Americas, Europe, Africa, and Oceania contributed with $12.5 \%, 8.1 \%, 10.7 \%$, and $0.3 \%$, respectively. In the production of dried fruit, the ranking is analogous (FAO, 2018).

Fruit weight, length, and diameter are important quality characters in many horticultural crops (RÊGO et al., 2016). Thus, evaluating the behavior of these characters throughout the crop cycle is fundamental for the researcher when making decisions aimed to the development of appropriate management techniques and harvesting fruits at appropriate growth stages.

Sigmodal or growth models are used to describe the behavior of various horticultural crops, being generally obtained using nonlinear regression models, such as the Logistic and von Bertalanffy models to used describe the production of zucchini (Cucurbita pepo L. ) and bell pepper (Capsicum annuиm L.) (LÚCIO et al., 2015); the Brody, Gompertz, Logistic, and von Bertalanffy models used to predict the number and fresh matter of eggplant fruits (Solanum melongena L.) (SARI et al., 2018); and the Logistic model used to describe dry matter accumulation of garlic (Allium sativum L.) (PUIATTI et al., 2018, 2020) and production of little beak pepper at different growing stages (DIEL et al., 2020).

In general, studies with nonlinear growth models are focused on model configuration, excluding parameter interpretation. In many cases, the best model is selected based on measurements of fit quality and/or selection criteria. Consequently, a model can be selected based only on satisfactory estimates of these criteria, although the existence of high nonlinearity can lead to misinterpretations of parametric values (SARI et al., 2019).

In addition, these models present information in average terms, being subjected to fitting problems caused by the presence of extreme values or deviations in data distribution. Alternatively, the fitting of growth curves using nonlinear quantile regression models has the ability to correct and/or minimize these problems (PUIATTI et al., 2018).

Quantile regression (KOENKER and BASSETT, 1978) is a flexible statistical tool with a vast number of applications that complement mean regression. This methodology has the capacity to extract inferences on individuals that are below or above the conditional average of the population (KOENKER and GELING, 2001). However, there are still few studies that used new tools, such as nonlinear quantile regression, to describe fruit growth.

Therefore, this work fits nonlinear regression models to model the characters fruit length and width of pepper genotypes (Capsicum annuum L.) over time using the method of ordinary least squares (OLS); identifies the model with the best fit; and compares it to the model obtained via nonlinear quantile regression in the $0.25,0.5$, and 0.75 quantiles. 


\section{Material and methods}

The five following commercial genotypes of pepper (Capsicum annuиm L.) were evaluated: Vulcão, Picante para vaso, Peter, Cayene, and Jamaica Yellow. The experiment was conducted from December 2017 to July 2018 in a greenhouse belonging to the olericulture sector of the Department of Plant Science, Federal University of Viçosa (UFV), municipality of Viçosa, mesoregion of Zona da Mata, Minas Gerais State, Brazil (20 45' $\mathrm{S}$ and $42^{\circ} 51^{\prime} \mathrm{W}$, average altitude of $650 \mathrm{~m}$ ).

The characters evaluated were fruit length (FL) and fruit width (FW), expressed in millimeters, which were measured weekly in ten periods beginning from seven days after flowering (DAF).

Three nonlinear regression models - Logistic (1), Gompertz (2), and von Bertalanffy (3) - were fitted using the ordinary least squares method (OLS) for each genotype:

$$
\begin{gathered}
y_{i}=\frac{\beta_{1}}{1+\beta_{2} e^{\left[-\beta_{3} x_{i}\right]}+\varepsilon_{i}} \\
y_{i}=\beta_{1} e^{\left[-\beta_{2} e^{\left(-\beta_{33 i}\right)}\right]}+\varepsilon_{i} \\
y_{i}=\beta_{1}\left[1-\beta_{2} e^{\left(-\beta_{3} x_{i}\right)}\right]^{3}+\varepsilon_{i}
\end{gathered}
$$

where $y_{i}$ is the fruit length or width, expressed in millimeters (response variable); $x_{i}$ represents the character evaluation periods (DAF - independent variable); $\beta_{1}, \beta_{2}$, and $\beta_{3}$ are the parameters that describe, respectively, the asymptotic length or width of the fruit; the integration factor, which is distance between the initial value and the asymptote; and the daily growth rate of genotypes; and $\varepsilon_{\mathrm{i}}$ is the random error, $\varepsilon_{\mathrm{i}} \sim \mathrm{N}\left(0, \sigma_{\varepsilon}^{2}\right)$.

For comparison among models, the following four fit quality evaluators were used: residual mean absolute deviation (4), Akaike information criterion (5), and curvature measures of Bates and Watts (1988), according to the expressions below:

$$
D M A=\frac{1}{n} \sum_{i=1}^{n}\left|\left(y_{i}-\hat{y}_{i}\right)\right|
$$

where $n$ is the number of observations, $y_{i}$ is observed value of the character in question, and $\hat{y}_{i}$ is the estimated value of the character in question by the model analyzed; 


$$
A I C=-2 \log L(\hat{\theta})+2 k
$$

where $\mathrm{L}(\hat{\theta})$ is the maximum of the likelihood function and $\mathrm{k}$ the number of model parameters;

According to Bates and Watts (1980), nonlinearity can be decomposed into the following two measures: curvature caused by the effect of parameters (EP) and the intrinsic curvature of the model (IN). EP is associated with deviations in uniformity and parallelism from the tangent plane corresponding to the parameterization of the model. IN is associated with deviations from the flatness expected of the surface, which is generated by the model in the vicinity of the location of the least squares solution and invariant to the reparametrizations of the model. The smaller the value of the two nonlinear measures, the closer the nonlinear model to the linear model, in which these values are zero. Thus, asymptotic results are more accurate and consequently inferences are more reliable, even in small samples (SEBER and WILD, 1989; ZEVIANI et al., 2012).

After the best model was identified, it was compared to those obtained using nonlinear quantile regression $(\mathrm{QR})$, according to quantiles $(\tau) 0.25,0.5$, and 0.75 , in order to describe the growth of pepper genotypes over time. QR models were fitted according to the interior points algorithm proposed by Koenker and Park (1996). This methodology aims to compute quantile regression estimates when the response function is nonlinear in the parameters. The models are specified similarly. However, there is a $\tau$ weighting associated with each parameter, where $\tau$ is the value of the quantile adopted, $0.25,0.50$, and 0.75 in the case ( $\tau$ $\in[0.1])$. For fitting nonlinear quantile regression models, the nlrq function of the quantreg package was used (KOENKER, 2016).

For comparison between the fit quality of models, the four fit quality evaluators aforementioned were adopted. All computational analyzes were performed with the statistical software R (R CORE TEAM, 2020).

\section{Results and discussion}

Estimates of fruit length (FL) ranged from 19.0987 to $75.5574 \mathrm{~mm}$ in models fitted by the method of ordinary least squares (OLS), as shown in Table 1.

For the Vulcão, Cayene, and Peter genotypes, the Logistic model was the one that best described their behavior associated with the character FL. For genotypes Picante para vaso and Jamaica Yellow, the von Bertalanffy model was best indicated (Table 1). It is observed that the fit quality evaluators agreed in the selection of the best model, with lower values of AIC, DMA, EP, and IN, as shown in Table 1. For the study of fruit growth, the use of nonlinear models, such as the Logistic (LÚCIO et al., 2015; MUNIZ et al., 2017; SARI et al., 2019) and von Bertalanffy (LÚCIO et al., 2015; MUNIZ et al., 2017) stood out. 
Table 1 - Estimates of model parameters $\left(\hat{\beta}_{1}, \hat{\beta}_{2}, \hat{\beta}_{3}\right)$ obtained by ordinary least squares (OLS) and by the following fit quality evaluators: Akaike information criterion (AIC), residual mean absolute deviation (DMA), and parametric (EP) and intrinsic (IN) curvatures for the Gompertz (G), Logistic (L), and von Bertalanffy (vB) models regarding the character fruit length

\begin{tabular}{ccccccccc}
\hline \multirow{2}{*}{ Genotype } & Model & \multicolumn{3}{c}{ Parameters } & \multicolumn{4}{c}{ Evaluators } \\
\cline { 3 - 9 } & & $\hat{\beta}_{1}$ & $\hat{\beta}_{2}$ & $\hat{\beta}_{3}$ & AIC & DMA & EP & IN \\
\hline \multirow{3}{*}{ Vulcão } & $\mathrm{G}$ & 20.1613 & 1.6514 & 0.1609 & 28.0398 & 0.4887 & 0.4522 & 0.1752 \\
& $\mathrm{~L}$ & 20.0430 & 4.0294 & 0.2326 & $\mathbf{1 8 . 2 7 8 4}$ & $\mathbf{0 . 2 9 0 7}$ & $\mathbf{0 . 4 4 5 9}$ & $\mathbf{0 . 1 2 4 7}$ \\
& $\mathrm{vB}$ & 20.2112 & 0.4227 & 0.1404 & 30.7171 & 0.5621 & 0.6055 & 0.2230 \\
\hline \multirow{2}{*}{ Picante } & $\mathrm{G}$ & 19.1307 & 0.9540 & 0.2544 & 9.2871 & 0.2327 & 0.2324 & 0.0850 \\
para vaso & $\mathrm{L}$ & 19.0987 & 1.5894 & 0.3188 & 11.6489 & 0.2599 & 0.2637 & 0.0889 \\
& $\mathrm{vB}$ & 19.1409 & 0.2727 & 0.2355 & $\mathbf{8 . 3 1 4 9}$ & $\mathbf{0 . 2 2 1 1}$ & $\mathbf{0 . 2 2 0 7}$ & $\mathbf{0 . 0 7 5 6}$ \\
\hline \multirow{3}{*}{ Peter } & $\mathrm{G}$ & 51.6905 & 3.6155 & 0.1423 & 45.7640 & 1.2217 & 0.7624 & 0.2868 \\
& $\mathrm{~L}$ & 51.2288 & 12.0537 & 0.2056 & $\mathbf{2 6 . 4 1 3 4}$ & $\mathbf{0 . 4 5 1 1}$ & $\mathbf{0 . 4 4 7 8}$ & $\mathbf{0 . 0 7 5 0}$ \\
& $\mathrm{vB}$ & 51.5671 & 1.0289 & 0.1396 & 49.7959 & 1.2927 & 1.0580 & 0.2352 \\
\hline \multirow{3}{*}{ Cayene } & $\mathrm{G}$ & 75.2287 & 3.1447 & 0.1369 & 45.8915 & 0.9945 & 0.4753 & 0.1732 \\
& $\mathrm{~L}$ & 74.3656 & 10.2503 & 0.2027 & $\mathbf{3 2 . 6 6 2 9}$ & $\mathbf{0 . 7 1 9 6}$ & $\mathbf{0 . 3 8 1 5}$ & $\mathbf{0 . 0 7 0 1}$ \\
& $\mathrm{vB}$ & 75.5574 & 0.7655 & 0.1203 & 53.1765 & 1.3801 & 0.8448 & 0.1936 \\
\hline \multirow{2}{*}{ Jamaica } & $\mathrm{G}$ & 32.4349 & 1.3926 & 0.0939 & 28.9639 & 0.6524 & 0.3263 & 0.1037 \\
Yellow & $\mathrm{L}$ & 32.0695 & 2.6249 & 0.1253 & 37.1788 & 0.9783 & 0.5528 & 0.1844 \\
& $\mathrm{vB}$ & 32.6126 & 0.3800 & 0.0838 & $\mathbf{2 4 . 6 6 8 6}$ & $\mathbf{0 . 5 1 7 2}$ & $\mathbf{0 . 1 9 2 1}$ & $\mathbf{0 . 0 4 1 7}$ \\
\hline Thenyyyyyyyyy
\end{tabular}

The best values of quality measures for each genotype are indicated in bold.

Regarding parameter estimates, it was found that for $\hat{\beta}_{1}$, corresponding to the asymptotic length of the fruit, the values obtained were relatively close when comparing OLS and RQR methods for each genotype individually. For example, for the Vulcão genotype, $\hat{\beta}_{1}$ assumed the following values: 20.0430 (OLS) and 19.4000, 19.9401, and 19.9509 for quantiles $0.25,0.5$, and 0.75 , respectively (Table 2).

For the estimator $\hat{\beta}_{2}$, the values obtained showed greater variation, although not representing inconsistency in the fitted models. Bem et al. (2018) observed that, when $\hat{\beta}_{2}$ values were low, the critical points obtained by the partial derivatives of the function (inflection, maximum acceleration, and maximum deceleration) were reached more quickly. Therefore, this parameter could be used to determine early harvest yield.

For $\hat{\beta}_{3}$, regarding fruit growth rate, correlation between the lowest values of asymptotic length of fruits and the highest values of growth rate was observed. In this case, for the Vulcão genotype, the lowest estimate of the asymptotic length of fruits was obtained in the 0.25 quantile (19.4000), as well as the highest estimate of fruit growth rate $(0.2583)$, as shown in Table 2 . 
Table 2 - Estimates of model parameters $\left(\hat{\beta}_{1}, \hat{\beta}_{2}, \hat{\beta}_{3}\right)$ obtained by QR and OLS and by the following fit quality evaluators: Akaike information criterion (AIC), residual mean absolute deviation (DMA), and parametric (EP) and intrinsic (IN) curvatures for the Logistic (L), and von Bertalanffy (vB) models regarding the character fruit length

\begin{tabular}{|c|c|c|c|c|c|c|c|c|}
\hline \multirow[b]{2}{*}{ Genotype } & \multirow[b]{2}{*}{$\tau$} & \multicolumn{7}{|c|}{ Logistic } \\
\hline & & $\hat{\beta}_{1}$ & $\hat{\beta}_{2}$ & $\hat{\beta}_{3}$ & AIC & DMA & EP & IN \\
\hline \multirow{4}{*}{ Vulcão } & 0.25 & 19.9400 & 5.5717 & 0.2583 & 4.4027 & 0,2547 & 0.3523 & 0.0790 \\
\hline & 0.50 & 19.9401 & 3.3348 & 0.2401 & 10.2608 & 0.2276 & 0.3402 & 0.1104 \\
\hline & 0.75 & 19.9509 & 3.3371 & 0.2489 & 3.6566 & 0.2314 & 0.2514 & 0.0821 \\
\hline & MQO & 20.0430 & 4.0294 & 0.2326 & 18.2784 & 0.2907 & 0.4459 & 0.1247 \\
\hline \multirow{4}{*}{ Peter } & 0.25 & 50.9609 & 13.6712 & 0.2146 & 9.8496 & 0.3343 & 0.2343 & 0.0368 \\
\hline & 0.50 & 51.0421 & 13.8022 & 0.2156 & 17.6273 & 0.3289 & 0.3305 & 0.0517 \\
\hline & 0.75 & 51.5417 & 8.4399 & 0.1887 & 29.8652 & 0.7853 & 0.2763 & 0.0558 \\
\hline & MQO & 51.2288 & 12.0537 & 0.2056 & 26.4134 & 0.4511 & 0.4478 & 0.0750 \\
\hline \multirow{4}{*}{ Cayene } & 0.25 & 74.5024 & 9.9288 & 0.1858 & 32.3390 & 0.9539 & 0.2216 & 0.0407 \\
\hline & 0.50 & 74.4927 & 9.1351 & 0.1945 & 31.0103 & 0.6423 & 0.2399 & 0.0466 \\
\hline & 0.75 & 75.1507 & 9.2246 & 0.1980 & 28.5064 & 0.8497 & 0.1957 & 0.0380 \\
\hline & MQO & 74.3656 & 10.2503 & 0.2027 & 32.6629 & 0.7196 & 0.3815 & 0.0701 \\
\hline \multirow{5}{*}{$\begin{array}{c}\text { Picante } \\
\text { para vaso }\end{array}$} & & \multicolumn{7}{|c|}{ von Bertalanffy } \\
\hline & 0.25 & 18.7895 & 0.2693 & 0.2377 & 9.3878 & 0.3155 & 0.2745 & 0.0981 \\
\hline & 0.50 & 19.3500 & 0.2764 & 0.2384 & 5.9501 & 0.1835 & 0.2767 & 0.0990 \\
\hline & 0.75 & 19.3501 & 0.2764 & 0.2384 & -2.1390 & 0.1835 & 0.2023 & 0.0685 \\
\hline & MQO & 19.1409 & 0.2727 & 0.2355 & 8.3149 & 0.2211 & 0.2207 & 0.0756 \\
\hline \multirow{4}{*}{$\begin{array}{l}\text { Jamaica } \\
\text { Yellow }\end{array}$} & 0.25 & 32.8712 & 0.3972 & 0.0759 & 20.4633 & 0.5434 & 0.1931 & 0.0486 \\
\hline & 0.50 & 31.3488 & 0.8529 & 0.1658 & 24.2176 & 2.2277 & 0.2680 & 0.0663 \\
\hline & 0.75 & 32.8945 & 0.3941 & 0.0925 & 20.5672 & 0.5528 & 0.1671 & 0.0541 \\
\hline & MQO & 32.6126 & 0.3800 & 0.0838 & 24.6686 & 0.5172 & 0.2685 & 0.0784 \\
\hline
\end{tabular}

The nonlinear quantile regression $(\mathrm{QR})$ model showed superior results than OLS for all genotypes evaluated. Specifically, for the Vulcano and Jamaica Yellow genotypes, both quantiles were superior, with at least three out of four quality evaluators with desirable values, i.e., lower, as shown in Table 2. For the Peter genotype, quantiles 0.25 and 0.5 stood out, while quantiles 0.5 and 0.75 were superior for genotypes Cayene and Picante para vaso, respectively (Table 2 ).

In Figure 1, genotype behavior is observed when the Logistic (on the left) and the von Bertalanffy (on the right) models are adopted in the scenarios aforementioned, corroborating with the results above. 

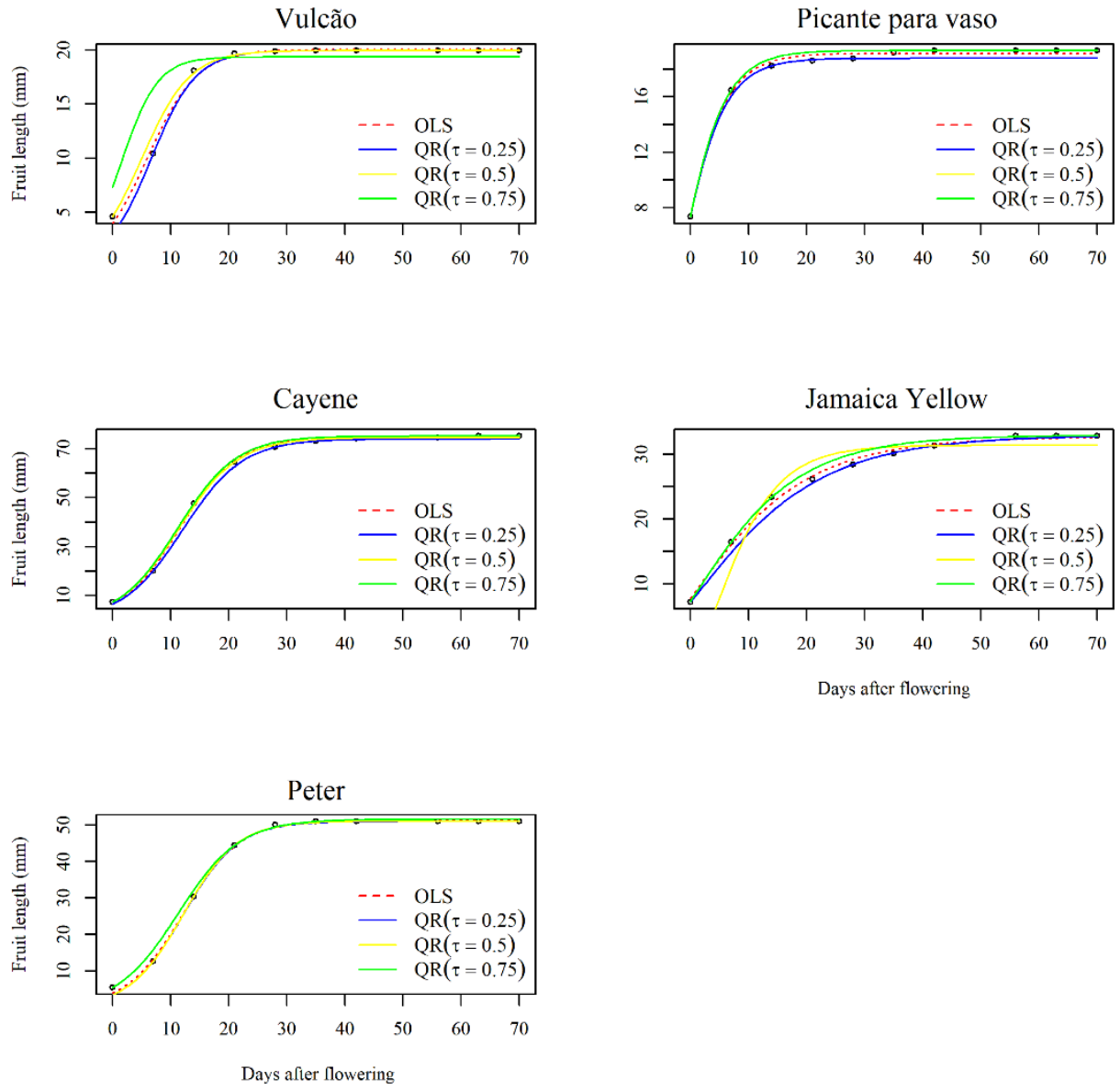

Figure 1 - Growth curves of the character fruit length fitted by the Logistic (right) and von Bertalanffy (left) models for the genotypes under study.

Estimates of the asymptotic width of the fruit (FW) ranged from 7.3182 to 29.7202 $\mathrm{mm}$ in models fitted by the method of ordinary least squares (OLS), as shown in Table 3.

The results of the best models according to OLS were similar to those obtained for FL, that is, for the genotypes Vulcão, Peter, and Cayene, the Logistic model presented the best results from quality evaluators and the von Bertalanffy model was superior than others for the Jamaica Yellow genotype, as shown in Table 3.

In contrast, the Picante para vaso genotype obtained satisfactory results from the Gompertz and von Bertalanffy models (Table 3 ). In this case, the model was selected according to the character fruit length (FL) and as a function of IN, since the EP 
measurement could be minimized with the use of reparametrization, as mentioned by Bates and Watts (1980). Thus, the von Bertalanffy model was selected.

Table 3 - Estimates of model parameters $\left(\hat{\beta}_{1}, \hat{\beta}_{2}, \hat{\beta}_{3}\right)$ obtained by ordinary least squares and by the following fit quality evaluators: Akaike information criterion (AIC), residual mean absolute deviation (DMA), and parametric (EP) and intrinsic (IN) curvatures for the Gompertz (G), Logistic (L), and von Bertalanffy (vB) models regarding the character fruit width

\begin{tabular}{ccccccccc}
\hline \multirow{2}{*}{ Genotype } & Model & \multicolumn{3}{c}{ Parameters } & \multicolumn{3}{c}{ Evaluators } \\
\cline { 3 - 9 } & & $\hat{\beta}_{1}$ & $\hat{\beta}_{2}$ & $\hat{\beta}_{3}$ & AIC & DMA & EP & IN \\
\hline \multirow{3}{*}{ Vulcão } & $\mathrm{G}$ & 8.9516 & 1.7520 & 0.1222 & 18.4353 & 0.3118 & $\mathbf{0 . 6 5 9 4}$ & 0.2263 \\
& $\mathrm{~L}$ & 8.8657 & 4.3861 & 0.1793 & $\mathbf{1 1 . 0 1 9 1}$ & $\mathbf{0 . 2 0 3 5}$ & 0.6671 & $\mathbf{0 . 1 8 4 1}$ \\
& $\mathrm{vB}$ & 8.9933 & 0.4415 & 0.1049 & 20.8483 & 0.3545 & 0.9628 & 0.2668 \\
\hline \multirow{2}{*}{ Picante } & $\mathrm{G}$ & 7.3442 & 1.1233 & 0.1896 & -6.7768 & $\mathbf{0 . 0 8 6 1}$ & $\mathbf{0 . 2 1 0 9}$ & 0.0992 \\
para vaso & $\mathrm{L}$ & 7.3182 & 2.0434 & 0.2502 & $\mathbf{- 5 . 7 7 2 9}$ & 0.0955 & 0.2648 & 0.1165 \\
& $\mathrm{vB}$ & 7.3544 & 0.3130 & 0.1722 & $\mathbf{- 6 . 7 8 8 6}$ & 0.0875 & 0.2427 & $\mathbf{0 . 0 9 5 3}$ \\
\hline \multirow{3}{*}{ Peter } & $\mathrm{G}$ & 20.8499 & 2.8499 & 0.1116 & 38.8469 & 0.8823 & $\mathbf{1 . 0 4 6 6}$ & 0.3428 \\
& $\mathrm{~L}$ & 20.6208 & 9.1961 & 0.1670 & $\mathbf{3 0 . 1 4 8 1}$ & $\mathbf{0 . 5 3 8 4}$ & 1.0647 & $\mathbf{0 . 2 0 2 1}$ \\
& $\mathrm{vB}$ & 21.0802 & 0.6428 & 0.0920 & 42.1419 & 1.0853 & 1.0580 & 0.2352 \\
\hline \multirow{3}{*}{ Cayene } & $\mathrm{G}$ & 11.1769 & 1.9680 & 0.0903 & 14.0823 & 0.2820 & 0.4696 & 0.1280 \\
& $\mathrm{~L}$ & 11.0238 & 4.8749 & 0.1294 & $\mathbf{4 . 5 1 3 8}$ & $\mathbf{0 . 1 7 0 8}$ & $\mathbf{0 . 3 7 6 7}$ & $\mathbf{0 . 0 9 5 5}$ \\
& $\mathrm{vB}$ & 11.2678 & 0.4942 & 0.0774 & 17.6102 & 0.3408 & 1.0288 & 0.1618 \\
\hline \multirow{2}{*}{ Jamaica } & $\mathrm{G}$ & 29.3576 & 1.4482 & 0.0593 & 35.5249 & 0.8129 & $\mathbf{0 . 7 9 8 1}$ & 0.1215 \\
Yellow & $\mathrm{L}$ & 28.7268 & 2.7292 & 0.0805 & 40.5204 & 1.0469 & 0.8584 & 0.1851 \\
& $\mathrm{vB}$ & 29.7202 & 0.3947 & 0.0520 & $\mathbf{3 3 . 2 7 5 9}$ & $\mathbf{0 . 7 2 4 6}$ & 0.9617 & $\mathbf{0 . 0 7 4 2}$ \\
\hline
\end{tabular}

The best values of quality measures for each genotype are indicated in bold.

For the character FW, it is observed that at least one of the models obtained by QR showed results superior to OLS according to the AIC and DMA fit quality evaluators for all genotypes evaluated, as shown in Table 4.

In the comparison between QR and OLS, it was identified that quantiles 0.25 and 0.75 were more suitable for the Vulcão genotype, obtaining the best values for three out of the four quality evaluators. For the Peter genotype, quantiles 0.25 and 0.5 were successful for all quality evaluators. For the Cayene genotype, the 0.25 quantile was superior according to OLS. In the von Bertalanffy models, quantiles 0.25 and 0.5 were indicated for the Jamaica Yellow genotype, being superior for three and four quality evaluators, respectively, according to OLS (Table 4).

Thus, it is observed that the mean is not the most indicated option to describe the growth of pepper genotypes. Similar results were observed by Puiatti et al. $(2018,2020)$ when evaluating dry matter accumulation in the garlic crop.

For the Cayene and Picante para vaso genotypes, quantiles 0.25 and 0.5, respectively, obtained similar results according to OLS, obtaining higher values for two out of four quality evaluators. 
Table 4 - Estimates of model parameters $\left(\hat{\beta}_{1}, \hat{\beta}_{2}, \hat{\beta}_{3}\right)$ obtained by QR and OLS and by the following fit quality evaluators: Akaike information criterion (AIC), residual mean absolute deviation (DMA), and parametric (EP) and intrinsic (IN) curvatures for the Logistic (L), and von Bertalanffy (vB) models regarding the character fruit width

\begin{tabular}{|c|c|c|c|c|c|c|c|c|}
\hline \multirow{2}{*}{ Genotype } & \multirow[b]{2}{*}{$\tau$} & \multicolumn{7}{|c|}{ Logistic } \\
\hline & & $\hat{\beta}_{1}$ & $\hat{\beta}_{2}$ & $\hat{\beta}_{3}$ & AIC & DMA & EP & IN \\
\hline \multirow{4}{*}{ Vulcão } & 0.25 & 8.7800 & 8.4347 & 0.2363 & -7.8694 & 0.1379 & 0.6767 & 0.1370 \\
\hline & 0.50 & 8.7836 & 8.4312 & 0.2361 & 0.2029 & 0.1376 & 0.9552 & 0.1934 \\
\hline & 0.75 & 8.8220 & 2.9918 & 0.1839 & 2.6838 & 0.2180 & 0.4965 & 0.1634 \\
\hline & MQO & 8.8657 & 4.3861 & 0.1793 & 11.0191 & 0.2035 & 0.6671 & 0.1841 \\
\hline \multirow{4}{*}{ Peter } & 0.25 & 20.3216 & 13.8403 & 0.1914 & 13.8640 & 0.4085 & 0.6242 & 0.0955 \\
\hline & 0.50 & 20.3274 & 12.4156 & 0.1862 & 21.2290 & 0.3938 & 0.8059 & 0.1308 \\
\hline & 0.75 & 20.9372 & 4.4955 & 0.1424 & 33.5329 & 0.9485 & 0.5027 & 0.1358 \\
\hline & MQO & 20.6208 & 9.1961 & 0.1670 & 30.1481 & 0.5384 & 1.0647 & 0.2021 \\
\hline \multirow{4}{*}{ Cayene } & 0.25 & 10.9182 & 4.7768 & 0.1249 & -2.8924 & 0.1577 & 0.3880 & 0.0982 \\
\hline & 0.50 & 10.8893 & 5.0486 & 0.1321 & 5.1454 & 0.1762 & 0.5672 & 0.1422 \\
\hline & 0.75 & 10.9829 & 4.8111 & 0.1431 & 0.8873 & 0.1939 & 0.4365 & 0.1141 \\
\hline & MQO & 11.0238 & 4.8749 & 0.1294 & 4.5138 & 0.1708 & 0.3767 & 0.0955 \\
\hline \multirow{5}{*}{$\begin{array}{c}\text { Picante } \\
\text { para vaso }\end{array}$} & & \multicolumn{7}{|c|}{ von Bertalanffy } \\
\hline & 0.25 & 7.3805 & 0.3133 & 0.1663 & -5.4126 & 0.0746 & 0.3594 & 0.1643 \\
\hline & 0.50 & 7.4100 & 0.3142 & 0.1649 & -13.522 & 0.0693 & 0.3367 & 0.1540 \\
\hline & 0.75 & 7.4101 & 0.3142 & 0.1910 & -15.624 & 0.0930 & 0.2844 & 0.1252 \\
\hline & MQO & 7.3544 & 0.3130 & 0.1722 & -6.7886 & 0.0875 & 0.2427 & 0.0953 \\
\hline \multirow{4}{*}{$\begin{array}{l}\text { Jamaica } \\
\text { Yellow }\end{array}$} & 0.25 & 28.8429 & 0.4165 & 0.0545 & 28.0727 & 0.7459 & 0.4038 & 0.0551 \\
\hline & 0.50 & 30.9093 & 0.3900 & 0.0448 & 31.8098 & 0.6685 & 0.7140 & 0.0640 \\
\hline & 0.75 & 30.2932 & 0.4045 & 0.0524 & 34.6634 & 0.7320 & 0.4901 & 0.062 \\
\hline & MQO & 29.7202 & 0.3947 & 0.0520 & 33.2759 & 0.7246 & 0.9617 & 0.0742 \\
\hline
\end{tabular}

Interpretations for the estimates of parameters $\left(\hat{\beta}_{1}, \hat{\beta}_{2}, \hat{\beta}_{3}\right)$ are similar to those obtained for the character FL, as shown in Table 2. As an example, quantile-based models showed their best suitability for the Vulcão genotype, confirming the results above (Figure 2). 

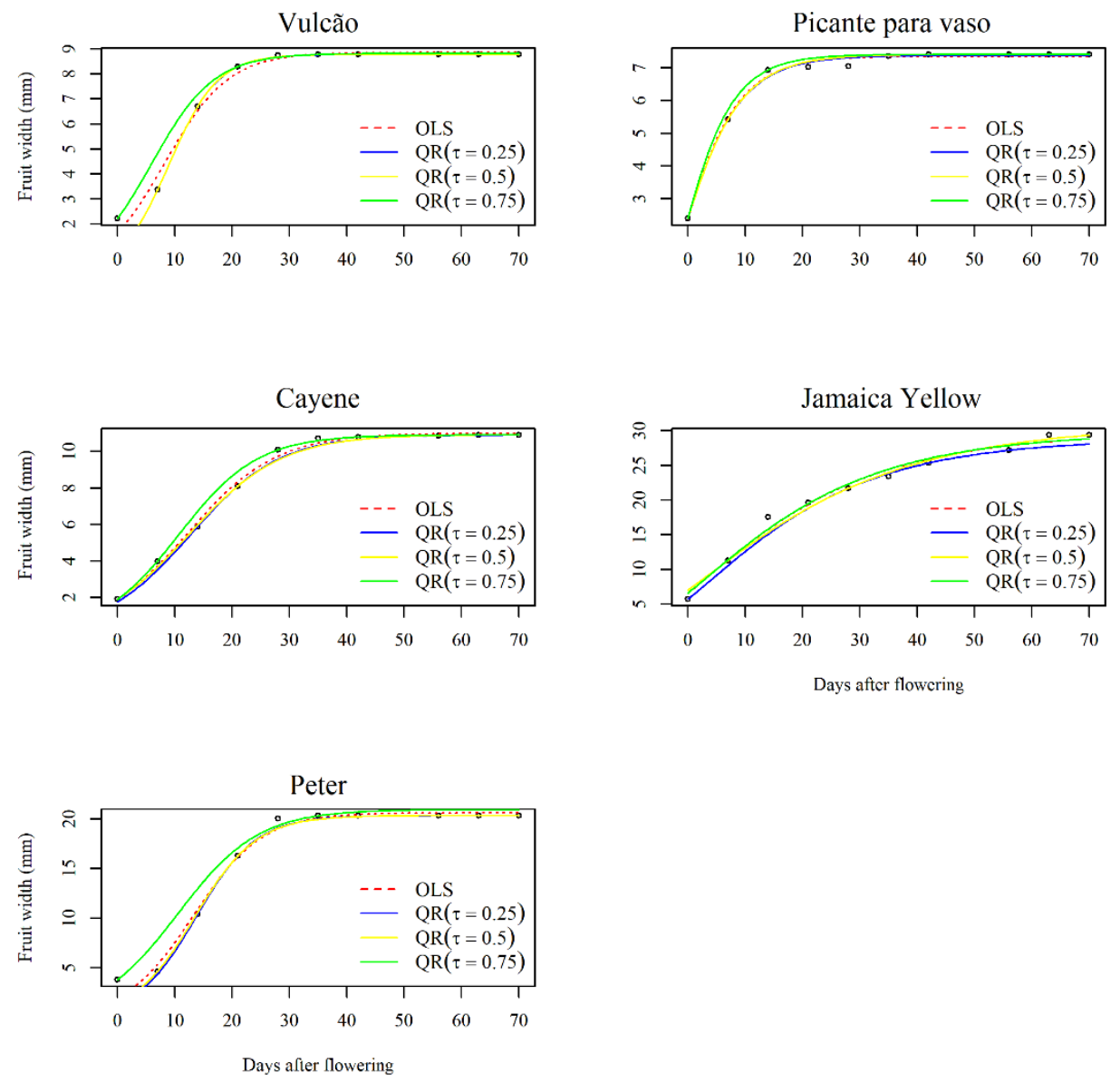

Figure 2 - Growth curves of the character fruit width fitted by the Logistic (right) and von Bertalanffy (left) models for the genotypes under study. 


\section{Conclusions}

The Logistic and von Bertalanffy nonlinear regression models were indicated to model the characters fruit length and width of pepper genotypes.

The nonlinear quantile regression $(\mathrm{QR})$ was efficient to fit models to model the character fruit length of pepper genotypes when compared to the nonlinear regression obtained by ordinary least squares. For the character fruit width, QR was efficient to three out of the five genotypes, being a valuable alternative in the study of fruit growth.

\section{Acknowledgement}

The authors would like to thank the Research Support Foundation of Minas Gerais State (FAPEMIG), the Coordination for the Improvement of Higher Education Personnel (CAPES), the National Council for Scientific and Technological Development (CNPq) for financially supporting this research, and the reviewers and editor for their comments and suggestions.

OLIVEIRA, A. C. R.; CECON, P. R.; PUIATTI, G. A.; GUIMARÃES, M. E. S.; CRUZ, C. D.; FINGER, F. L.; NASCIMENTO, M.; PUIATTI, M.; LACERDA, M. S. Modelos não lineares baseados em quantis no ajuste de curvas de crescimento de genótipos de pimenta. Rev. Bras. Biom. Lavras, v.39, n.3, p.447-459, 2021.

- RESUMO: Este estudo teve por objetivos ajustar modelos de regressão não linear para modelar o crescimento dos caracteres comprimento do fruto $(C F)$ e largura do fruto $(L F)$ de genótipos de pimenta (Capsicum annuum L.) ao longo do tempo, por meio do método dos mínimos quadrados ordinários (MQO); identificar o modelo com melhor ajuste, e posteriormente, compará-lo ao obtido via regressão quantílica não linear $(R Q)$, nos quantis $0,25,0,5$ e 0,75. Foram adotados três modelos de regressão (Logístico, Gompertz e von Bertalanffy) e quatro avaliadores de qualidade de ajuste: critério de informação de Akaike, desvio médio absoluto dos resíduos e medidas de curvaturas paramétrica e intrínseca. Foram avaliados cinco genótipos comerciais de pimenta, sendo os caracteres CF e LF avaliados semanalmente, iniciando aos sete dias após o florescimento e, totalizando dez mensurações. Na estimação por MQO, os modelos Logístico e von Bertalanffy foram considerados adequados, com base nos avaliadores de qualidade. Na comparação entre os modelos acima, por meio de $M Q O$ e $R Q$, verifica-se a superioridade dos modelos obtidos via $R Q$, para o caractere $C F$. Para o caractere $L F$, a eficiência da $R Q$ foi observada em três dos cinco genótipos, sendo portanto uma alternativa valiosa no estudo de crescimento de frutos.

- PALAVRAS-CHAVE: Capsicum annuum; mínimos quadrados ordinários; regressão quantílica.

\section{References}

BATES, D.M.; WATT S, D.G. Nonlinear regression analysis and its applications. New York: John Wiley \& Sons, 1988. 365 p.

BEM, C. M.; CARGNELUTTI FILHO, A.; CHAVES, G. G.; KLEINPAUL, J. A.; PEZZINI, R. V.; LAVEZO, A. Gompertz and logistic models to the productive traits of sunn hemp. Journal of Agricultural Science, v.10, n.1; p.225-238, 2018. 
CABRAL, N. S. S.; MEDEIROS, A. M.; NEVES, L. G.; SUDRÉ, C. P.; PIMENTA, S.; COELHO, V. J.; SERAFIM, M. E.; RODRIGUES, R. Genotype x environment interaction on experimental hybrids of chili. Genetics and Molecular Research, v.16, n.2, gmr16029551, 2017.

DIEL, M. I.; LÚCIO, A. D. C.; VALERA, O. V. S.; SARI, B. G.; OLIVOTO, T.; PINHEIRO, M. V. M.; MELO, P. J.; TARTAGLIA, F. L.; SCHMIDT, D. Production of biquinho pepper in different growing seasons characterized by the logistic model and its critical points. Ciência Rural, v.50, n.4, e20190477, 2020.

FAO. Statistic Database. Rome, Italy: FAOSTAT, 2018. Disponível em: http://www.fao.org/faostat/en/\#data/QC

HWANG, D. G.; PARK, J. H.; LIM, J. Y.; KIM, D.; CHOI, Y.; KIM, S.; REEVES, G.; YEOM, S. I.; LEE, J. S.; PARK, M.; KIM, S.; CHOI, I. Y.; CHOI, D.; SHIN, C. The hot pepper (Capsicum апnиum) microRNA transcriptome reveals novel and conserved targets: a foundation for understanding microRNA functional roles in hot pepper. PLoS One, v.8, n.5, e64238, 2013.

JARRET, R. L.; BARBOZA, G. E.; BATISTA, F.R. C.; BERKE, T. CHOU, YU-YU; HULSE-KEMP, A.; OCHOA-ALEJO, N.; TRIPODI, P.; VERES, A.; GARCIA, C. C.; CSILLERY, G.; HUANG, YUNG-KUANG; KISS, E.; KOVACS, Z.; KONDRAK, M.; ARCE-RODRIGUEZ, M. L.; SCALDAFERRO, M. A.; SZOKE, A. Capsicum - an abbreviated compendium. Journal of the American Society for Horticultural Science, v.144, n.1, p.3-22, 2019.

KOENKER R. quantreg: Quantile Regression. R package version 5.21, 2016.

KOENKER, R.; BASSET, G. Regression quantiles. Econometrica, New Haven, v.46, n.1, p.33-50, 1978.

KOENKER, R.; GELING, O. Reappraising medfly longevity: a quantile regression survival analysis. Journal of the American Statistical Association, v.96, n.454, p.458-468, 2001.

KOENKER, R.; PARK, B. J. An interior point algorithm for nonlinear quantile regression. Journal of Econometrics, v.71, n.1-2, p.265-283, 1996.

LÚCIO, A. D. C.; NUNES, L. F.; REGO, F. Nonlinear models to describe production of fruit in Cucurbita pepo and Capsicum annuum. Scientia Horticulturae, v.193, n.22, p.286293, 2015.

MUNIZ, J. A.; NASCIMENTO, M. S.; FERNANDES, T. J. Nonlinear models for description of cacao fruit growth with assumption violations. Revista Caatinga, v.30, n.1, p.250-257, 2017.

NEITZKE, R. S.; FISCHER, S. Z.; VASCONCELOS, C. S.; BARBIERI, R. L.; TREPTOW, R. O. Pimentas ornamentais: aceitação e preferências do público consumidor. Horticultura Brasileira, v.34, n.1, p.102-109, 2016.

PICKERSGILL, B. Genetic resources and breeding of Capsicum spp. Euphytica, v.96, n.1, p.129-133, 1997.

PUIATTI, G. A.; CECON, P. R.; NASCIMENTO, M.; NASCIMENTO, A. C. C.; CARNEIRO, A. P. S.; SILVA, F. F.; PUIATTI, M.; CRUZ, C. D. Nonlinear quantile 
regression to describe the dry matter accumulation of garlic plants. Ciência Rural, v.50, n.1, e20180385, 2020.

PUIATTI, G. A.; CECON, P. R.; NASCIMENTO, M.; NASCIMENTO, A. C. C.; CARNEIRO, A. P. S.; SILVA, F. F.; PUIATTI, M.; OLIVEIRA, A. C. R. Quantile regression of nonlinear models to describe different levels of dry matter accumulation in garlic plants. Ciência Rural, Santa Maria, v.48, n.1, e20170322, 2018.

R CORE TEAM. $R$ : a language and environment for statistical computing. R Foundation for Statistical Computing, Vienna, Austria. 2020.

RÊGO E. R.; RÊGO, M. M.; FINGER, F. L. Production and Breeding of Chilli Peppers (Capsicum spp.). Springer, Cham, 2016. 146 p.

SARI, B. G.; LÚCIO, A. D. C.; SANTANA, C. S.; OLIVOTO, T.; DIEL, M. I.; KRYSCZUN, D. K. Nonlinear growth models: An alternative to ANOVA in tomato trials evaluation. European Journal of Agronomy, v.104, n.1, p.21-36, 2019.

SARI, B. G.; OLIVOTO, T.; DIEL, M. I.; KRYSCZUN, D. K.; LÚCIO, A. D. C.; SAVIAN, T. V. Nonlinear modeling for analyzing data from multiple harvest crops. Agronomy Journal, v.110, n.6, p.2331-2342, 2018.

SASU, L.; MODOSA, E.; VELICEVICI, G.; CIULCA, S.; AVADANEI, C.; GORINOIU, G. Studies regarding correlations between the main morphological traits in a collection of bell pepper (Capsicum annuum var. grossum) local landraces. Journal of Horticulture, Forestry and Biotechnology, v.17, n.2, p.285-289, 2013.

SEBER, G. A. F.; WILD, C. J. Nonlinear regression. NewYork: J. Wiley, 1989. 752p.

TRIPODI, P.; FICCADENTI, N.; ROTINO, G. L.; FESTA, G.; BERTONE, A.; PEPE, A.; CARAMANICO, R.; MIGLIORI, C. A.; SPADAFORA, D.; SCHIAVI, M.; CARDI, T.; SCALZO, R. L. Genotypic and environmental effects on the agronomic, health-related compounds and antioxidant properties of chilli peppers for diverse market destinations. Journal of the Science of Food and Agriculture, v.99, n.10, p.4550-4560, 2019.

ZEVIANI, W. M.; SILVA, C. A.; CARNEIRO, W. J. O.; MUNIZ, J. A. Modelos não lineares para a liberação de potássio de estercos animais em latossolos. Ciência Rural, v.42, n.10, p.1789-1796, 2012.

Received on 03.05.2021

Approved after revised on 30.08.2020 